\title{
The modelling of prenuclear accents in Central Catalan declaratives*
}

\section{Eva Estebas-Vilaplana}

Universidad Nacional de Educación a Distancia

Departamento de Lenguas Extranjeras y sus Lingüísticas

Edificio de Humanidades

C/ Senda del Rey, 7. 28040 Madrid

eestebas@flog.uned.es

\begin{abstract}
The aim of this paper is to examine the phonetic and phonological properties of prenuclear accents in Central Catalan declaratives within the Autosegmental-Metrical approach of intonational analysis. Prenuclear accents show a rising movement whose peak tends to be aligned after the accented syllable. Three possible interpretations for the modelling of such rises are considered: 1) an $\mathrm{H}^{*}$ with peak delay, 2) a bitonal accent $\left(\mathrm{L}^{*}+\mathrm{H}\right)$, and 3$)$ the combination of two different tones, namely, a pitch accent $\left(\mathrm{L}^{*}\right)$ and a word edge tone $(\mathrm{H})$. Words with different stress distributions (oxytones, paroxytones and proparoxytones) are analysed to observe whether the presence of a word boundary has an effect on the location of the F0 peak. The results show that the F0 peak is consistently anchored at the end of the word no matter the number of post-accented syllables. Thus, prenuclear rises in Central Catalan declaratives are interpreted as a combination of an $\mathrm{L}^{*}$ pitch accent and an $\mathrm{H}$ word edge tone.
\end{abstract}

Key words: prenuclear accents, alignment, association, peak delay, bitonality, word edge tones.

\section{Introduction}

\subsection{The Autosegmental-Metrical approach}

In this study the phonetic and phonological properties of prenuclear accents in Central Catalan neutral declaratives are examined within the tenets of the Autosegmental-Metrical (AM) approach of intonational analysis (Pierrehumbert 1980, Beckman and Pierrehumbert 1986, Pierrehumbert and Beckman 1988, Beckman and Hirschberg 1994, Ladd 1996, among many others). Within the AM approach, pitch patterns ${ }^{1}$ consist of a sequence of categorically distinctive entities,

* I wish to express my most sincere thanks to the staff of the Department of Phonetics and Linguistics of University College London, where this research has been carried out. I would also like to thank José I. Hualde, Pilar Prieto and Lluïsa Astruc for reading this paper and giving me very inspiring comments.

1. In this paper, the terms «pitch» and «F0» are used interchangeably. Pitch is the perceptual sensation of fundamental frequency (F0), which is the acoustic correlate of vocal fold vibration. 
associated to elements of the segmental string and to the edges of prosodic domains. The association of these entities to the text is governed by principles of prosodic organisation, according to which either prominent syllables or prosodic edges are possible anchors for the phonological events. There are three kinds of phonological events: the pitch accents which consist of local F0 movements that accompany prominent syllables (stressed syllables), the phrase accents that mark the end of an intermediate phrase and the boundary tones that signal the end of an intonational phrase. The tonal properties of pitch accents, phrase accents and boundary tones are transcribed as $\mathrm{H}$ and $\mathrm{L}$, which stand for relatively high and relatively low F0 targets. The rhythmic properties are indicated by assigning an asterisk [*] following the tone that marks a pitch accent, a hyphen [-] after the tone for the phrase accent, and [\%] after the tone for the boundary tone. Whereas phrase accents and boundary tones are only monotonal $(\mathrm{H}-, \mathrm{L}-, \mathrm{H} \%, \mathrm{~L} \%)$, pitch accents can be both monotonal $\left(\mathrm{H}^{*}, \mathrm{~L}^{*}\right)$ and bitonal $\left(\mathrm{L}^{*}+\mathrm{H}, \mathrm{L}+\mathrm{H}^{*}, \mathrm{H}^{*}+\mathrm{L}, \mathrm{H}+\mathrm{L}^{*}\right)$. Bitonal accents can be left-headed or right-headed depending on whether the first or the second element of the accent is associated to the metrically strong syllable. As in monotonal pitch accents, the tone associated with the accented syllable is marked with an asterisk.

Several studies (Silverman and Pierrehumbert 1990, Prieto et al. 1994, 1995, among others) have shown that at the phonetic level the synchronisation between an F0 feature and a prominent syllable is not always perfect. Sometimes the F0 peak corresponding to an $\mathrm{H}^{*}$ pitch accent is not realised within the accented syllable but aligned considerably later. Thus, studies have drawn a distinction between association and alignment (Ladd 1983, 1996). Whereas association is an abstract structural property, alignment is a phonetic property of the timing of F0 events and segmental events. Studies on the alignment of F0 contours in several languages have argued that the location of peaks in $\mathrm{H}^{*}$ pitch accents depends on a number of factors, such as segmental duration, the presence of word or phrase boundaries, and stress clash contexts, among others. F0 peaks are more delayed as the duration of the accented syllable increases and retracted when adjacent to a word, an intermediate phrase or an intonation phrase boundary and in stress clash contexts (Steele and Altom 1986, and Silverman and Pierrehumbert 1990 for American English, Prieto et al. 1994, 1995 for Mexican Spanish).

\subsection{Modelling prenuclear accents}

Several studies have shown that in many languages prenuclear accents in neutral declarative structures involve a rising movement, whose peak tends to be aligned after the accented syllable. However, the phonological interpretation of such rises varies cross-linguistically and sometimes studies on the same language maintain competing views for the phonological description of such rises. Prenuclear rises, for example, have been widely studied in Greek, yet no conclusion on the best way to categorise them has been reached. Arvaniti and Ladd (1995) and also the Greek version of the ToBI system (Arvaniti and Baltazani 1999) propose the $\mathrm{L}^{*}+\mathrm{H}$ bitonal pitch accent to describe prenuclear rises. Arvaniti and Ladd argue for this accent 
due to the stability in the alignment and in the scaling of the starred L. However, further research in Greek (Arvaniti et al. 1998, 2000) shows that even though to describe rising prenuclear movements in Greek a bitonal accent seems to be required $(\mathrm{LH})$, there is no clear evidence of which of the two tones is aligned with the accented syllable and hence it is difficult to decide which is the starred tone. The $\mathrm{L}^{*}+\mathrm{H}$ accent type is now ruled out because $\mathrm{H}$ does not exhibit the stable alignment predicted by bitonality, where the trailing tone is expected to follow the starred tone by a fixed interval (Grice 1995), and also because in clash contexts, $\mathrm{L}^{*}$ is more robust than $\mathrm{H}$. Similarly, the option $\mathrm{L}+\mathrm{H}^{*}$ is discarded, since $\mathrm{L}$ does not precede $\mathrm{H}^{*}$ by a fixed interval. A further possibility is investigated, namely, the idea that $\mathrm{H}$ is an edge tone that marks the end of the accented word. However, this option is also discarded since in words with antepenultimate stress the $\mathrm{H}$ is located relative to the accented syllable and not at the word edge. Finally, the possibility of using two starred tones $\left(\mathrm{L}^{*} \mathrm{H}^{*}\right)$ is left open. Their proposal for two starred tones is based on the fact that both $\mathrm{L}$ and $\mathrm{H}$ are aligned relative to the stressed syllable despite being realised outside its boundaries.

Similar controversial views have been argued for Spanish prenuclear rises. Some studies on Spanish intonation (Prieto et al. 1994, 1995, and Nibert 2000), have classified prenuclear rises as $\mathrm{H}^{*}$. Phonetically, these accents present two characteristics: 1) a rise in F0 that takes place during the accented syllable and 2) a displaced peak where the F0 maximum of prenuclear $\mathrm{H}^{*} \mathrm{~s}$ is not located within the accented syllable but after it. Prieto et al. have shown that the amount of peak delay is subject to factors such as segmental duration or an upcoming prosodic boundary. On the other hand, Sosa (1999) and Face $(1999,2001)$ have postulated a different interpretation for the rising movement of prenuclear accents in Spanish, namely, $\mathrm{L}^{*}+\mathrm{H}$. This accent involves a low F0 within the accented syllable and a sharp rise after the accented syllable. More recently, Hualde (2002) finds that neither $\mathrm{H}^{*}$ nor $\mathrm{L}^{*}+\mathrm{H}$ describe prenuclear rises in Spanish satisfactorily. He claims that $\mathrm{H}^{*}$ fails to account for the fact that the tone is low at the onset of the stressed syllable. However, he discards $\mathrm{L}^{*}+\mathrm{H}$ on the basis that it is not contrastive with $\mathrm{L}+\mathrm{H}^{*}$. He proposes, like Arvaniti et al. (2000) for Greek, a pitch accent where both tones are associated with the stressed syllable $(\mathrm{L}+\mathrm{H})^{*}$.

In this paper, we will analyse prenuclear accents in Central Catalan neutral declaratives. Particular attention will be devoted to identifying the types of phonological entities and their phonetic realisations. The data will show that neither a monotonal accent nor a bitonal one will suffice to describe the F0 movements on prenuclear rises and that two tonal entities (a pitch accent and a word edge tone) are required.

\section{Data}

The data consisted of 64 Subject-Verb-Object positive declarative sentences produced with a neutral intonation. The number of stresses per sentence varied between 3 and 5.6 female speakers of the Central variety of Catalan were asked to read the sentences. The informants were between 24 and 32 years old at the 
time of the recordings and had similar educational, social and geographical backgrounds. In this paper, the informants are identified as DV, CP, ER, MC, NG, and NM. In order to obtain a neutral intonation, the informants were asked to read the list of sentences as if they were replies to a «what happens?» question type. Overall, 384 utterances were gathered. The list of sentences is included in the Appendix.

The recordings included two simultaneous but separate signals: speech and laryngeal (Lx) signals. For the speech signal, a Marantz Superscope/CD 330 tape recorder and a Beyer Dynamic microphone were used. For the laryngeal signal, a portable laryngograph LX 12 with two electrodes was used. A Thandar portable DRO 26 oscilloscope was also used to check the activity of the vocal folds. The recordings were conducted in a soundproof room of a private recording studio in Ripoll.

Auditory and acoustic analyses of the data were performed. The acoustic analysis was carried out by means of the Speech Filing System (SFS) program, which allowed us to obtain F0 traces from the laryngeal signal and perform a time-aligned inspection of the speech waveform and the F0 trace.

\section{Results}

The F0 traces for Central Catalan neutral declaratives present the following characteristics. Every time prenuclear stresses become accented, a rising movement is observed in the vicinity of the accented syllable. A progressively falling F0 movement is identified after the last prenuclear accent till the end of the sentence. An example of a neutral declarative F0 trace in Central Catalan is presented in Figure 1 for the sentence Les nenes haurien de donar l'enhorabona 'The girls should send their congratulations' where stressed syllables are under-



Figure 1. Les nenes haurien de donar l'enhorabona (speaker NG). 
lined. The top screen displays the speech waveform and the middle one the F0 trace. Finally, the bottom screen annotates the beginning of each syllable allowing us to observe the synchronisation between the segmental level and the F0 movements. For each prenuclear accented syllable, the F0 rise seems to start within the limits of the syllable but it is unclear the location of the peak. In some cases, as in nenes and haurien, the peak is located after the accented syllable. In other cases, as in donar, the peak is anchored at the end of the accented syllable.

\section{Interpretation}

Previous studies on Central Catalan declarative intonation have shown heterogeneity of interpretations as far as prenuclear rises are concerned. For example, Prieto $(1995,1997)$ classifies those rises as $\mathrm{H}^{*}$ (with a delayed peak) on an acoustic basis, since the start of the rise takes place within the accented syllable. Bonet (1984), on the other hand, interprets prenuclear accents as low tones associated to the accented syllable since she perceives the peak of the rise after the offset of the stressed syllable. In this paper, prenuclear rises in Central Catalan declaratives are examined in detail. Three possible analyses are taken into consideration: 1) an $\mathrm{H}^{*}$ pitch accent with peak delay (as in Prieto 1995, 1997), 2) a bitonal accent $\left(\mathrm{L}^{*}+\mathrm{H}\right)$, and 3$)$ an $\mathrm{L}^{*}$ pitch accent followed by an $\mathrm{H}$ word edge tone. The option $\mathrm{L}+\mathrm{H}^{*}$ will not be examined because we assume that, with respect to the properties of the starred tone (i.e. with respect to the location of the peak and the onset of the rise), the same behaviour is expected for $\mathrm{H}^{*}$ and $\mathrm{L}+\mathrm{H}^{*}$. Also the possibility of using two starred tones $\left(\mathrm{L}^{*} \mathrm{H}^{*}\right)$ is not considered because the data will provide evidence for one of the aforementioned analyses. First, the option $\mathrm{L}^{*}+\mathrm{H}$ vs. $\mathrm{H}^{*}$ is examined and finally the $\mathrm{L}^{*} \mathrm{H}$ analysis is considered.

Theoretically, $\mathrm{L}^{*}+\mathrm{H}$ differs from $\mathrm{H}^{*}$ with a peak delay in two aspects: 1) the location of the onset of the rise, and 2) the location of the peak. Whereas in $\mathrm{H}^{*}$ accents the F0 rise starts at the onset of the accented syllable, in $\mathrm{L}^{*}+\mathrm{H}$ the $\mathrm{F} 0$ is «low for a good portion of the accented syllable, and then rises sharply, often into the following syllable if there is one» (Ladd, 1996). The second aspect that differentiates $\mathrm{H}^{*}$ with peak delay and $\mathrm{L}^{*}+\mathrm{H}$ is the location of the peak. In $\mathrm{H}^{*}$ the placement of the peak is partly predicted as a function of the segmental duration of the rhyme or syllable (Steele and Altom 1986, Silverman and Pierrehumbert 1990, Prieto et al. 1995) among other factors. In the bitonal accent, on the other hand, the trailing tone is expected to be located at a fixed distance with respect to the starred tone (Grice 1995, Arvaniti et al. 2000). Our data suggested that: 1) there is variation in the location of the start of the rise, and 2) the location of the peak seems to be neither dependent on the syllable duration nor placed at a fixed distance with respect to the accented syllable. In fact, the peak seems to be located near the end of the word. These two aspects are examined in more detail in the following sections. 


\subsection{Start of the rise}

For all observations, the only aspect that presents regularity among speakers is the low F0 at the onset of the accented syllable. However, the location of the rise with respect to this low onset shows inter- and intra-speaker variability. Whereas sometimes the rise takes place within the accented syllable, at other times the accented syllable is low and the rise occurs over the post-accented syllable. This is illustrated in Figure 2, which presents the mean F0 value at the onset and offset of the accented syllable and at the peak for all speakers. The graphs show that whereas for speakers CP and NM the rise starts after the syllable offset, for the other speakers the F0 starts to rise during the accented syllable.
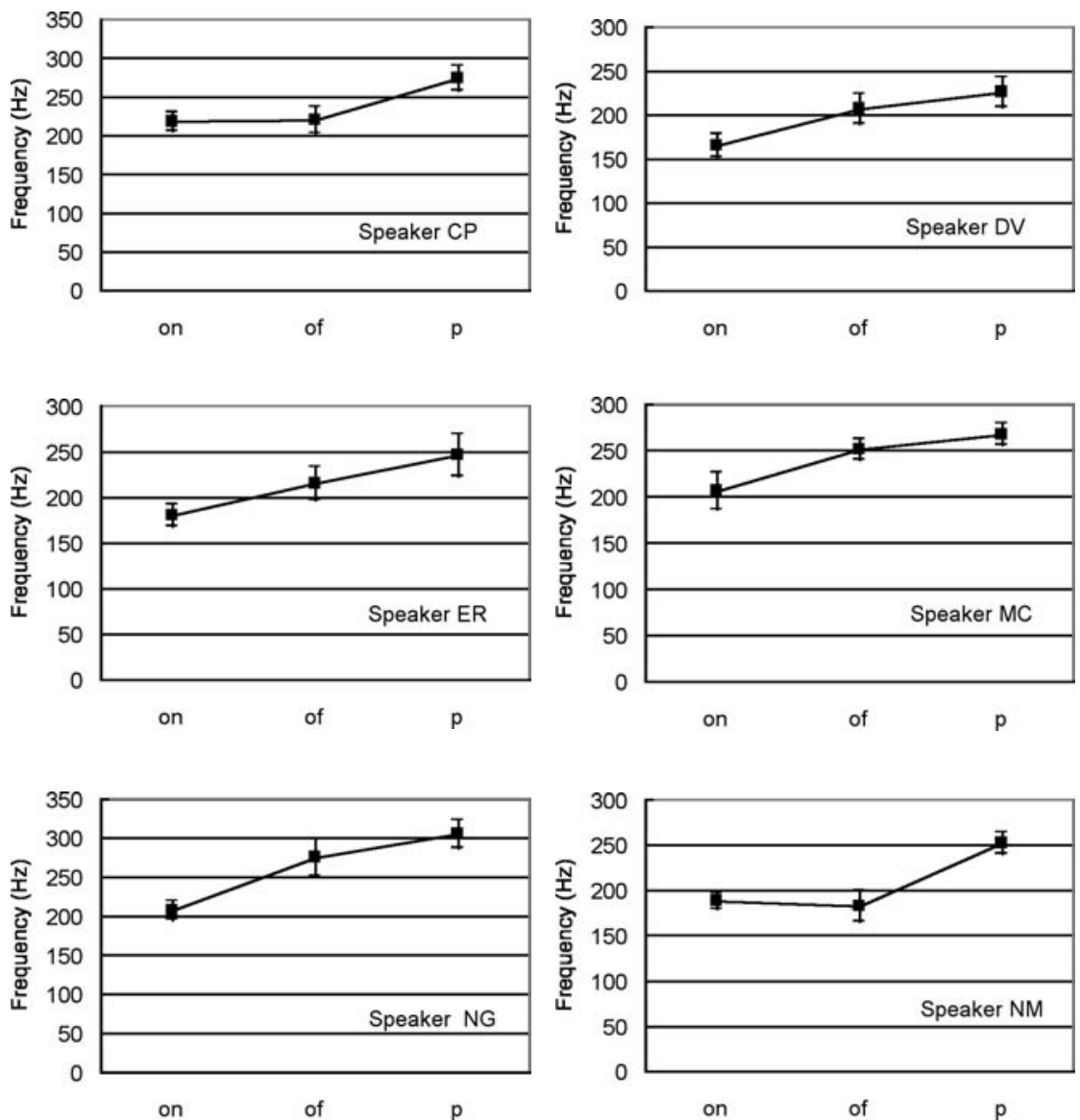

Figure 2. Mean F0 values at the onset (on) and offset (of) of prenuclear accented syllables and at the peak (p) for all speakers. The lines below and above the squares indicate the mean values minus and plus the standard deviation respectively. 
The question that arises from these observations is whether the two phonetic patterns correspond to two phonologically contrastive units (as $\mathrm{H}^{*}$ and $\mathrm{L}^{*}+\mathrm{H}$ respectively) or whether they can be interpreted as allotonic variations of the same category. In languages, such as English (Pierrehumbert 1980), Dutch (Ladd 1992) and Portuguese (Frota 2000) contrastive differences between prenuclear $\mathrm{H}^{*}$ and $\mathrm{L}^{*}+\mathrm{H}$ have been observed. However, a perception test performed on two Central Catalan speakers showed that the phonetic differences observed between these two patterns were not perceived as contrastive in Catalan. Thus, both patterns can be classified as phonetic realisations of the same phonological entity (see EstebasVilaplana 2000 for more details on the perception test).

\subsection{Location of the peak}

One of the characteristics of Central Catalan prenuclear accents is that the peak of the rise is neither placed at a fixed distance after the starred tone, as it would be in the case of an $\mathrm{L}^{*}+\mathrm{H}$ pitch accent (Grice 1995, Arvaniti et al. 2000), nor dependent on the syllable duration, as expected in $\mathrm{H}^{*}$ (Steele and Altom 1986, Silverman and Pierrehumbert 1990, Prieto et al. 1995). In order to confirm these claims empirically, the following measurements were obtained for all prenuclear accents of the six informants ${ }^{2}: 1$ ) the distance between the onset of the accented syllable and the location of the peak (on-peak), and 2) the distance between the onset and the offset of the accented syllable, i.e. duration of the accented syllable (on-of).

If Central Catalan prenuclear accents corresponded to $\mathrm{L}^{*}+\mathrm{H}$, no correlation between the two variables would be expected, that is, $\mathrm{L}^{*}+\mathrm{H}$ would involve a fairly fixed «on-peak» distance indicating that the location of the peak is unchanging, no matter what the duration of the syllable is. Alternatively, if prenuclear accents were characterised as $\mathrm{H}^{*}$ with a delayed peak, a strong correlation between the two variables would be expected. This would indicate that the location of the peak could be explained as a function of syllable duration, that is, the longer the duration of the accented syllable, the longer the delay of the peak.

In order to observe the relation between the two variables, correlations were performed for the measurements of all speakers. The results are presented in Figure 3. The graphs plot the distance between the onset of the accented syllable and the location of the peak (on-peak) against the duration of the syllable (on-of) in seconds for all prenuclear accents of all speakers. The regression lines summarise the correlation between the two variables. Correlation coefficients are displayed in each graph.

The results displayed in Figure 3 favour neither the interpretation of Central Catalan prenuclear accents as $\mathrm{L}^{*}+\mathrm{H}$, nor that of $\mathrm{H}^{*}$ with peak delay. On the one hand, the data show a low correlation between the location of the peak with respect to the onset of the accented syllable and the duration of the accented syllable. In

2. In this paper, we assume that the starred tone is located at the onset of the accented syllable. 

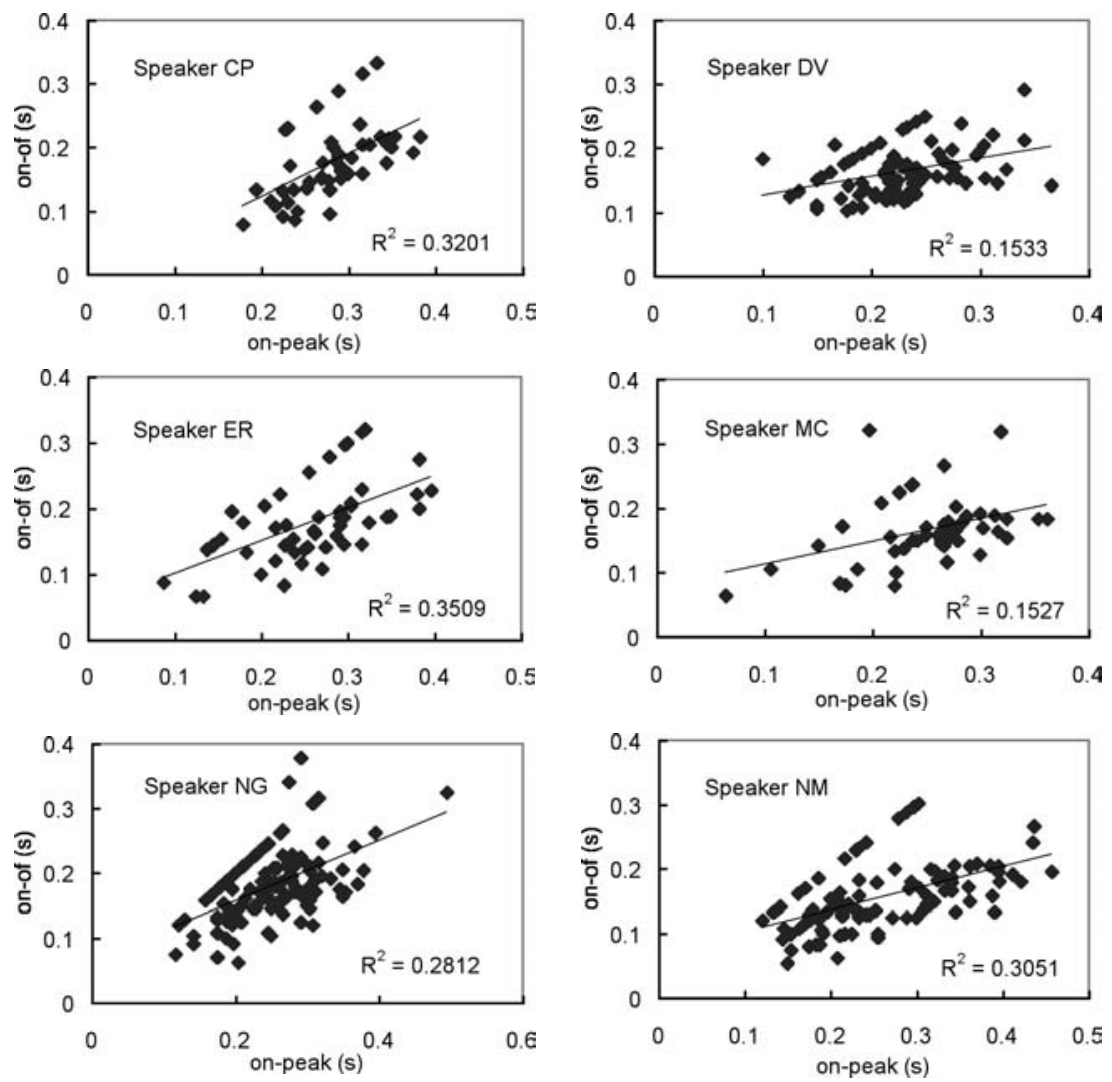

Figure 3. Distance between the onset of the accented syllable and the peak (on-peak) against distance between the onset and the offset of the accented syllable (on-of) in seconds for all prenuclear accents of all speakers.

all cases, $\mathrm{R}^{2}$ values are very low, ranging from 0.15 to 0.35 . This indicates that the placement of the peak cannot be explained as a function of syllable duration. Thus, the option of characterising prenuclear accents as $\mathrm{H}^{*}$ with peak delay is not supported by the evidence above. However, the alternative of describing prenuclear accents as $\mathrm{L}^{*}+\mathrm{H}$ is not entirely sustained either, since the «on-peak» distance is not as fixed as it would be expected by the bitonal accent. In Figure 3, two clusters of points can be spotted in each graph. At the top of each representation, a well-defined line of dots is observed, indicating that sometimes the distances «onof» and «on-peak» are clearly correlated. Looking at the F0 contours in more detail, cases where a clear correlation between the two variables were observed corresponded to words with stress on the last syllable. This suggests that maybe the peak of the rise is anchored at a word boundary. 
This possibility is considered in more detail in the next paragraphs with the following predictions: if the $\mathrm{H}$ signals the right edge of words, the peak will be anchored at the end of the word no matter how many unstressed syllables appear after the accented syllable. In oxytones (words with stress on the last syllable), the peak coincides with the end of the accented syllable, which is the last syllable of the word. In paroxytones (words with stress on the penultimate syllable), the peak is located at the offset of the post-stressed syllable, and in proparoxytones (words with stress on the antepenultimate syllable) at the offset of the second post-stressed syllable.

The possibility that the $\mathrm{H}$ is located at the end of the word was tested empirically by taking the following measurements from all prenuclear accents: 1) Distance between the onset of the accented syllable and the location of the peak (on-peak), and 2) distance between the onset of the accented syllable and the end of the word (on-end).

Once the measurements for all prenuclear pitch accents were obtained, the results were divided into two groups according to the stress distribution of the words available in the initial corpus: i.e. oxytones and paroxytones. Since proparoxytones were not included in the corpus, a few sentences with proparoxytones were gathered later on for one speaker to confirm the findings on the other stress patterns. First, the results on paroxytones and oxytones will be presented for all speakers and then the results of proparoxytones will be analysed.

The results of the measurements are presented in Figures 4 and 5 for paroxytones and oxytones respectively. The graphs plot the distance between the onset of the accented syllable and the location of the peak (on-peak) against the distance between the onset of the accented syllable and the end of the word (on-end). The regression lines summarise the correlations observed between the two variables. $\mathrm{R}^{2}$ values are included in each graph.

The results of Central Catalan prenuclear accents in neutral declaratives (Figures 4-5) show that for all speakers there is a strong correlation between the location of the peak with respect to the onset of the accented syllable and the distance between this onset and the end of the word. This is true for both paroxytones $\left(R^{2}\right.$ values vary between 0.7 and 0.89$)$ and oxytones $\left(R^{2}\right.$ values vary between 0.63 and 1). This indicates that the placement of peaks in Central Catalan prenuclear rises seems to be anchored at the end of the word, irrespective of the number of post-stressed syllables. These results show that in Central Catalan the location of the peak in prenuclear rises can be predicted as a function of word boundary. These findings are different from the results reported in Face (2001) for Madrid Spanish. He shows that in this language word boundaries do not affect the alignment of the F0 peak since in oxytones the F0 maximum is always located on the post-stressed syllable. A cross-linguistic study using similar data and analysis procedures in the two languages would be necessary to provide more details on those differences.

Although the results presented so far for oxytones and paroxytones seem consistent enough to conclude that prenuclear peaks in Central Catalan are anchored at the end of the word, it was considered necessary to confirm these 


\section{PAROXYTONES}
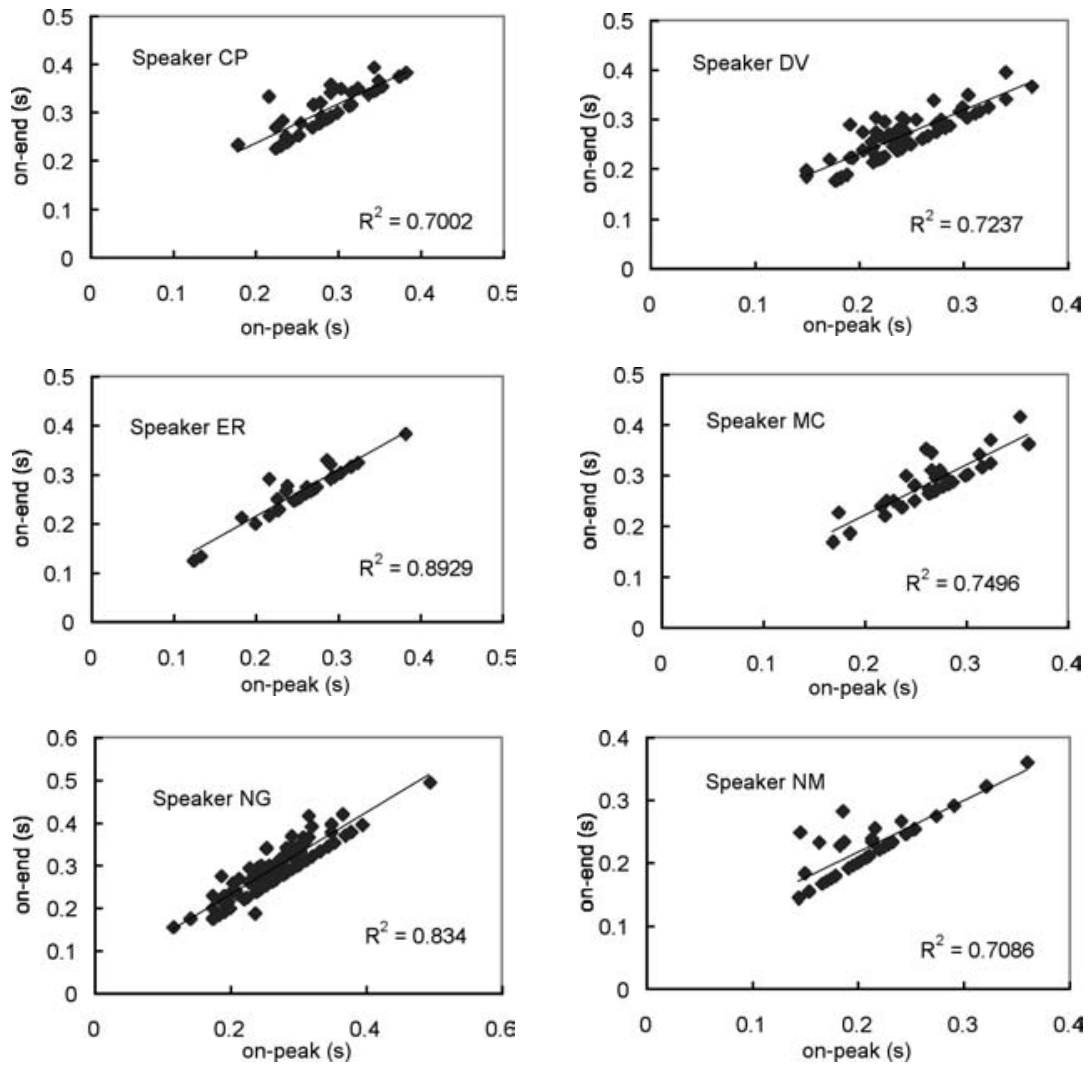

Figure 4. Distance between the onset of the accented syllable and the peak (on-peak) against distance between the onset of the accented syllable and the end of the word (on-end) in seconds for all speakers in paroxytones.

observations with the analysis of proparoxytones, that is, words which have two post-stressed syllables. Arvaniti et al. (2000) found that proparoxytones behave differently from oxytones and paroxytones in Greek. In proparoxytones, the alignment of the $\mathrm{H}$ is relative to the accented syllable and not to the following word-edge. Thus, a few sentences were designed which included proparoxytones in non-final sentence position. Overall, 30 sentences were designed with proparoxytones in initial and in medial sentence positions (see the Appendix for the list of sentences). All utterances were produced by one speaker (DV), who was recorded following the same procedures as described in section 2 . This informant was chosen due to the good quality of the F0 traces obtained in her previous recordings. 


\section{OXYTONES}
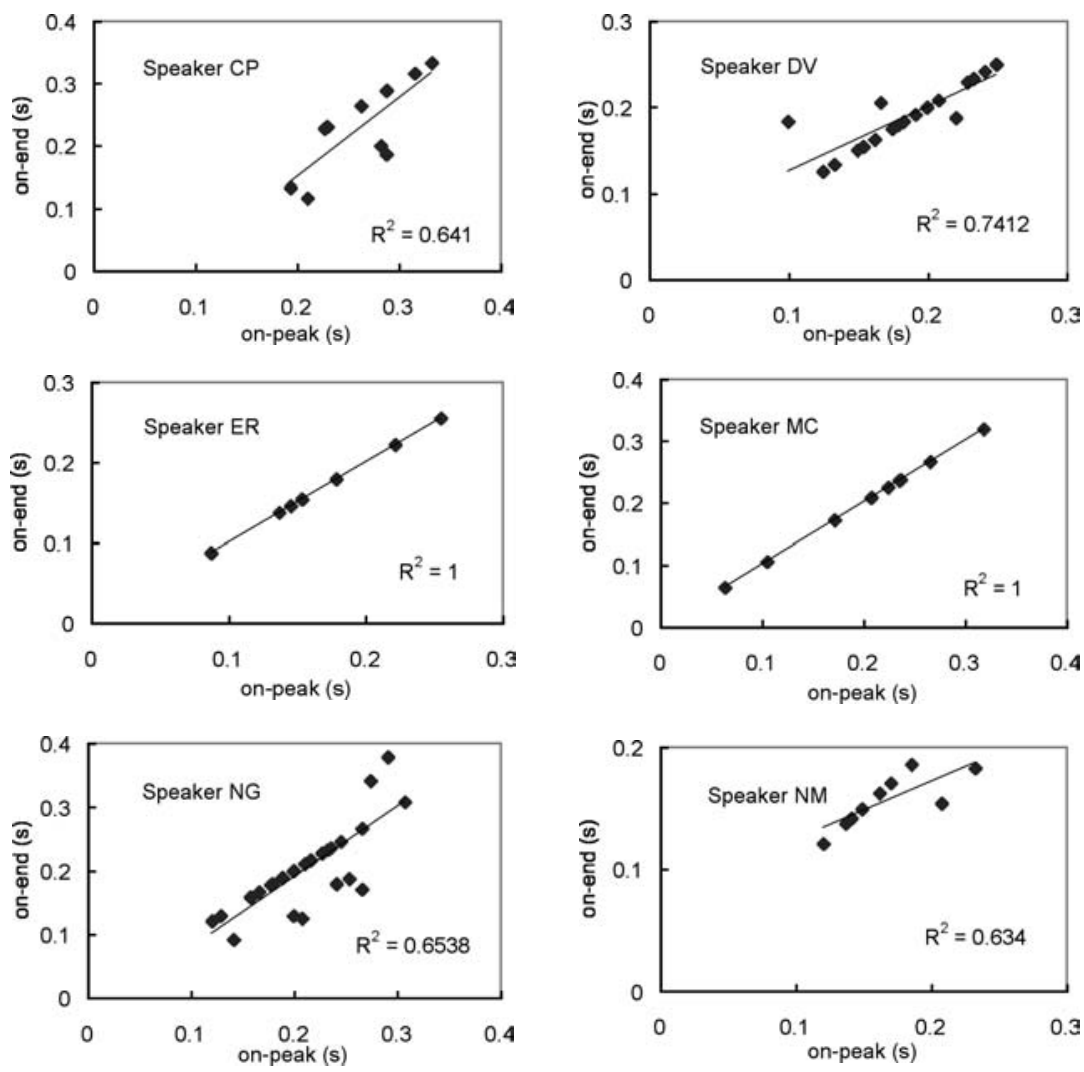

Figure 5. Distance between the onset of the accented syllable and the peak (on-peak) against distance between the onset of the accented syllable and the end of the word (on-end) in seconds for all speakers in oxytones.

The results of proparoxytones are presented in Figure 6. As before, the graph plots the distance between the onset of the accented syllable and the peak (on-peak) against the distance between the onset of the accented syllable and the end of the word (on-end) for speaker DV in proparoxytones.

Again the results show a strong correlation $\left(R^{2}=0.85\right)$ between the location of the peak and the location of the word boundary in proparoxytones. These results confirm the initial observations that the peak of prenuclear rises is anchored towards the end of the word no matter how many syllables follow the accented one. 


\section{PROPAROXYTONES}



Figure 6. Distance between the onset of the accented syllable and the peak (on-peak) against distance between the onset of the accented syllable and the end of the word (on-end) in seconds for speaker DV in proparoxytones.

\section{Discussion}

In this paper the phonetic and phonological properties of prenuclear accents in Central Catalan neutral declaratives have been examined. The results showed that prenuclear accents in Central Catalan involve an F0 rise in the vicinity of the accented syllable that can neither be interpret as an $\mathrm{H}^{*}$ with peak delay nor as a bitonal accent $\left(\mathrm{L}^{*}+\mathrm{H}\right)$. Instead the results suggest a combination of two tones: a pitch accent $\left(\mathrm{L}^{*}\right)$ and a word edge tone $(\mathrm{H})$. This disagrees with the representations proposed in earlier studies on Central Catalan intonation, namely, Prieto $(1995,1997)$ and Bonet (1984).

According to the results presented in this paper, Prieto's interpretation of nonfinal rises as $\mathrm{H}^{*}$ (with a peak delay) is thrown into doubt by the alignment of F0 peaks. The peak of prenuclear rises was consistently anchored at the end of the word. This was confirmed for words with different stress distributions (i.e. oxytones, paroxytones and proparoxytones), where the peak of the rise was aligned at the right end of the word, irrespective of the number of unstressed syllables. This suggested that the phonological representation of Central Catalan prenuclear rises involves an $\mathrm{L}^{*}$ pitch accent associated to the accented syllable and an $\mathrm{H}$ edge tone associated to the end of the word. The representation of prenuclear accents as $\mathrm{L}^{*}$ is consistent with the perceptual interpretation of Bonet (1984) who postulates a low tone in similar types of utterances.

The possibility of analysing prenuclear rises as $\mathrm{L}^{*}+\mathrm{H}$, as proposed in languages such as Greek (Arvaniti and Ladd 1995, Arvaniti and Baltazani 1999) or Spanish (Sosa 1999, Face 1999, 2001) was also taken into consideration. However, given the consistent location of $\mathrm{H}$ at the word boundary, the peak of prenuclear rises was considered to reflect some kind of prosodic domain rather than the trailing part of 
a bitonal accent. Furthermore, the peak was not aligned at a fixed position with respect to the starred tone, as it would have been predicted by bitonality. The consistent alignment of peaks at the right edge of accented words seems to strengthen the idea proposed in recent research (Arvaniti et al. 1998, Ladd 1996) that turning points in the F0 contour, such as peaks or valleys, have to be relevant for phonological structure. This means that prenuclear peaks either stand for the trailing tone of the bitonal $\mathrm{L}^{*}+\mathrm{H}$ or represent the end of a prosodic domain, as observed in our data. This proposal questions the notion of peak delay, which involves the interpretation of $\mathrm{F} 0$ peaks as phonetic realisations of $\mathrm{H}^{*} \mathrm{~s}$.

Finally, the findings reported in this paper have an important implication for phonological theory, namely, that the word domain seems to be relevant in Central Catalan as an anchor for tonal entities. In other words, Central Catalan may have an intonationally-defined word level, marked with the presence of a right-hand word edge tone. Studies have shown that languages might differ in terms of the levels of prosodic phrasing. In Japanese (Beckman and Pierrehumbert 1986, Pierrehumbert and Beckman 1988, Venditti 1999), in Korean (Jun 1996) and in French (Jun and Fougeron, 2000) a lower domain in the prosodic tree, called the accentual phrase, has been postulated ${ }^{3}$. The accentual phrase is a tonally defined domain. Thus, for example, in Japanese, the accentual phrase has at most one High tone and is delimited by a Low boundary tone. Furthermore, in Japanese and Korean, the notion of accent is different from Catalan. In Catalan, as in English, Spanish, and Italian, among other languages, a pitch accent is associated to the stressed syllable of the word. In Japanese and Korean, the «accent» is distributed among the accentual phrase and functions to delimit prosodic groupings of words rather than to mark prominent syllables. The possibility that the $\mathrm{H}$ tone observed at the end of accented words in Central Catalan signals an accentual phrase domain is ruled out on two grounds: 1) Central Catalan pitch accents are associated with stressed syllables, rather than distributed among an accentual phrase, and 2) there is no specific tonal pattern that can be attributed to a particular domain. Instead $\mathrm{H}$ is anchored at the end of a word and its presence is linked to the presence of a pitch accent. The consistent location of $\mathrm{H}$ at the end of accented words suggest that this tone might signal the end of a word domain, which might correspond to a phonological word domain or maybe a clitic group domain, as proposed by Selkirk (1984) and Nespor and Vogel (1986) on phonological-syntactic grounds. Although more research is needed on this topic, Central Catalan may have an intonationally-defined word level, marked with the presence of a right-hand word edge tone. Thus, the phonological primitives used to describe Central Catalan intonation are: 1) pitch accents associated to metrically strong syllables at a post-lexical level; 2) word edge tones marking the end of an accented word; 3) phrase accents signalling an intermediate phrase boundary; and 4) boundary tones marking the presence of an intonation phrase ${ }^{4}$.

3. The idea of an accentual phrase in French is not supported by recent work on French intonation within the AM framework (Post 2000).

4. Evidence for the presence of the intermediate phrase and the intonation phrase can be found in Estebas-Vilaplana (2000) and Prieto (1995, 2002). 
The presence of word edge tones has been postulated in other languages, such as Serbo-Croatian (Godjevac 2001). In this language, the phonological word is defined by two tonal events: a pitch accent and a word boundary tone. However, in contrast with Central Catalan the Serbo-Croatian word tone appears to be in initial word position $(\% \mathrm{~L})$. Despite differences in the location of word edge tones, both Central Catalan and Serbo-Croatian show that a word domain can be defined on intonational grounds.

\section{Conclusions}

In this paper, the phonetic and phonological properties of prenuclear accents in Central Catalan declaratives have been examined within the AM framework of intonational analysis. Three possible interpretations for the modelling of prenuclear rises in Central Catalan have been considered, namely, $\mathrm{H}^{*}$ with peak delay, a bitonal accent $\left(\mathrm{L}^{*}+\mathrm{H}\right)$ and two different tones: a pitch accent $\mathrm{L}^{*}$ and a word edge tone $(\mathrm{H})$. The results on the alignment of tones on words with different stress distributions (oxytones, paroxytones and proparoxytones) have shown that the F0 peak is consistently aligned at the end of the word no matter the number of post-accented syllables. Thus, prenuclear rises in Central Catalan declaratives have to be interpreted as $\mathrm{L}^{*} \mathrm{H}$, which involves an $\mathrm{L}^{*}$ pitch accent associated to the accented syllable and an $\mathrm{H}$ tone associated to the end of the accented word. This shows evidence that the word domain in Catalan can be defined on intonational grounds.

\section{References}

Arvaniti, Amalia; Baltazani, Mary (1999). «Greek ToBI». 14 $4^{\text {th }}$ International Conference of Phonetic Sciences Satellite Meeting. Workshop on «Intonation: Models and ToBI labeling». San Francisco.

Arvaniti, Amalia; Ladd, D. Robert (1995). «Tonal alignment and the representation of accentual targets». Proceedings of the $13^{\text {th }}$ International Conference of Phonetic Sciences, Stockholm, pp. 220-223.

Arvaniti, Amalia; Ladd, D. Robert; Mennen, Ineke (1998). «Stability of tonal alignment: the case of Greek prenuclear accents». Journal of Phonetics 26: 3-25.

- (2000). «What is a starred tone? Evidence from Greek». In: Broe, Michael; Pierrehumbert, Janet (eds). Papers in Laboratory Phonology V. Cambridge: CUP, pp. 119-131.

Beckman, Mary; Hirschberg, Julia (1994). «The ToBI annotation conventions. Ms. and accompanying speech materials». Ohio State University.

Beckman, Mary; Pierrehumbert, Janet (1986). «Intonational structure in Japanese and English». Phonology Yearbook 3: 255-310.

Bonet, Eulàlia (1984). Aproximació a l'entonació del català. Universitat Autònoma de Barcelona, master's thesis.

Estebas-Vilaplana, Eva (2000). The use and realisation of accentual focus in Central Catalan with a comparison to English. University College London, doctoral dissertation. 
Face, Timothy L. (1999). «A Phonological analysis of rising pitch in Castilian Spanish». Hispanic Linguistics 11.

- (2001). Intonational marking of contrastive focus in Madrid Spanish. The Ohio State University, doctoral dissertation.

Frota, Sónia (2000). Prosody and focus in European Portuguese: Phonological phrasing and intonation. New York: Garland.

Grice, Martine (1995). «Leading tones and downstep in English». Phonology 12: 183234.

Godjevac, Svetlana (2001). «Serbo-Croatian ToBI (SC_ToBI)». http://ling.ohiostate.edu/people/Alumni/dodjevac/

Hualde, José Ignacio (2002). «Intonation in Spanish and the other Ibero-Romance languages: overview and status quaestionis». In: Wiltshire, Caroline; Camps, Joaquim (eds.). Romance phonology and variation: Selected papers from the $30^{\text {th }}$ Linguistic Symposium of Romance Languages. Amsterdam: John Benjamins, pp. 101-116.

Jun, Sun-Ah (1996). The phonetics and phonology of Korean prosody. New York and London: Garland Publishing.

Jun, Sun-Ah; Fougeron, Cécile (2000). «A phonological model of French intonation». In: Botinis, Antonio (ed.). Intonation. Analysis, modelling and technology. Dordrecht: Kluwer, pp. 209-242.

Ladd, D. Robert (1983). «Phonological features of intonational peaks». Language 59: 721-759.

- (1992). «An introduction to intonational phonology». In: Docherty, Gerry J.; Ladd, D. Robert (eds.). Papers in Laboratory Phonology II. Cambridge: Cambridge University Press, pp. 321-334.

- (1996). Intonational Phonology. Cambridge: Cambridge University Press.

Nespor, Marina; Vogel, Irene (1986). Prosodic phonology. Dordrecht: Foris.

Nibert, Holy (2000). Phonetic and phonological evidence for intermediate phrasing in Spanish intonation. University of Illinois at Urbana-Champaign, doctoral dissertation.

Pierrehumbert, Janet (1980). The Phonology and Phonetics of English Intonation. MIT, doctoral dissertation.

Pierrehumbert, Janet; Beckman, Mary (1988). Japanese Tone Structure. Cambridge, MA: MIT Press.

Post, Brechtje (2000). Tonal and phrasal structures in French intonation. The Hague: Holland Academic Graphics.

Prieto, Pilar (1995). «Aproximació als contorns tonals del català central». Caplletra 19: 161-186.

- (1997). «Prosodic manifestation of syntactic structure in Catalan». In: MartínezGil, Fernando; Morales-Front, Alfonso (eds.). Issues in the Phonology and Morphology of the Major Iberian Languages. Washington, D.C.: Georgetown University Press, p. 179-199.

- (2002). «Entonació». In: Solà, Joan; Lloret, Maria Rosa; Mascaró, Joan; Pérez Saldanya, Manuel (eds.). Gramàtica del català contemporani. Vol.1. Barcelona: Edicions 62, pp. 395-462.

Prieto, Pilar; van Santen, Jan; Hirschberg, Julia (1994). «Patterns of F0 peak placement in Mexican Spanish». Proceedings of the ESCA/IEEE Workshop on Speech Synthesis. New Paltz, New York, pp. 33-37. 
- (1995). «Tonal alignment patterns in Spanish». Journal of Phonetics 23: 429-451.

Selkirk, Elisabeth (1984). Phonology and Syntax: the relation between sound and structure. Cambridge MA: MIT Press.

Silverman, Kim; Pierrehumbert, Janet (1990). «The timing of prenuclear high accents in English». In: Kingston, John; Beckman, Mary (eds.). Papers in Laboratory Phonology I. Cambridge: Cambridge University Press, pp. 72-106.

Sosa, Juan Manuel (1999). La entonación del español. Barcelona: Cátedra.

Steele, Shirley A.; Altom, M.J. (1986). «Nuclear stress: changes in vowel duration and F0 peak location». Technical Memorandum. AT\&T Bell Laboratories.

Venditti, Jennifer (1999). «The J_ToBI model of Japanese intonation». $14^{\text {th }}$ International Conference of Phonetic Sciences Satellite Meeting. Workshop on Intonation: Models and ToBI labeling. San Francisco.

\section{Appendix}

Sentences with oxytones and paroxytones

Jo menjava melmelada

L'Eva guarda monedes romanes

La Rosa llegia llibres

La Núria vol una germana menuda

Males modes malmeten els joves

Vàries joies eren lluminoses

Algunes minyones guarden mala lluna

Les roses vermelles eren oloroses

L'ou bullia a l'olla

L'illa brillava amb la llum de l'albada

L'Isidre du una gavardina vermella

La mare menja arengades

L'olla negra guardava mongetes

Les meves amigues eren bones nenes

La nena morena venia nines noves

L’ala nova dóna al jardí

L'au venia de l'illa

L'home venia llimones madures

La Mari du una sivella daurada

L'Emília vol amanida

Noies joves ballen munyeires

Vàries nenes lligaven els globus

La meva germana balla balades vieneses

Algunes havaneres eren alegres

Ell anava a Girona

L'Anna vivia a Vilavella

La núvia rentava la faldilla

L'Amèlia duia robes negres

L'home magre menjava vedella 


\section{L'amo murri viu a Badalona}

La minyona menuda netejava la nevera

La gallina rodona vivia a la granja

En Juli diu bajanades

La Mila nega la maionesa

Els homes llimaven l'armari

En Joan domina l'àlgebra

Les noies vénen de veure l'examen

Les ovelles volen jeure a l'herba

En Raimon volia arrü̈nar la germana

La Lluïsa havia d'arribar diumenge

La Glòria ve de Vilanova

La Rosa rega els geranis

En Joan anava al museu

La Mireia remena l'olla

Les noies volen rebre la reina

Les mares veuen riure les nenes

En Juli hauria de demanar l'hora

Les nenes haurien de donar l'enhorabona

En Jaume mou la galleda

En Jordi mira les mones

La Neus anima els alumnes

En Jordi guardava medalles

Els joves volen viure la vida

L'àvia va a raure a la masia

La Laura volia dividir l'herència

La mare havia de menjar verdura

La Marina beu llimonada

L'Emili mana els obrers

La Remei mima les nenes

En Ramon olora la benzina

L'Elena mira de moure el mobiliari

Els homes volen beure aiguardent

L'Elena volia munyir l'ovella

La Ramona volia mullar la roba

Sentences with proparoxytones

Note: In Catalan there are not many verbs with stress on the antepenultimate syllable. Hence, only two kinds of structures have been included in the data: the subjunctive forms of saber (sàpiga/sàpiguen) and cabre (càpiga/càpiguen) and a few imperative forms followed by a pronoun $(l i)$.

La làmina lluirà amb el sol

La Melanie mira les novel-les 
El número resulta massa gran

La mínima baixarà demà

La nòmina no serà més alta

La bòveda donava al carrer

La màquina lligava l'herba

La Mònica menjava mongetes

La màniga no es podrà allargar

El nòmada menjava al carrer

La música sonava molt brillant

L'ànima demanava descans

L'òliba dormia vora l'arbre

L'Àngela manejava l'ordinador

L'àrbitre demanava l'hora

L'íntegre no es podrà calcular

L'àguila volava sobre el mar

L'àncora tenia un gran valor

(És necessari que) en Jaume sàpiga la veritat

(És necessari que) els llibres càpiguen a l'armari

(És necessari que) la noia sàpiga la solució

(És necessari que) la nena càpiga dins la vànova

(És necessari que) els homes sàpiguen el camí

(És necessari que) els jugadors càpiguen a l'estadi

Ella va dir digue-li la veritat

Ell contestà amaga-li la veritat

La nena suggerí mira-li la mà

La dona digué nega-li la mà

La mare ve dir mima-li la nena

L'home va dir dóna-li la mandarina 